\title{
New locality records and additional information on habitats of three species of clam shrimps (Crustacea: Branchiopoda) from a region in northern part of Western Ghats (Sahyadris), India
}

\author{
Sameer M. Padhye ${ }^{1}$, Hemant V. Ghate ${ }^{2} \&$ Kalpana Pai ${ }^{3}$ \\ ${ }^{1}$ Research fellow, Department of Zoology, Pune University, Pune, Maharashtra 411007, India \\ ${ }^{2}$ Head, Department of Zoology, Modern College, Shivajinagar, Pune, Maharashtra 411 005, India \\ ${ }^{3}$ Associate Professor, Department of Zoology, University of Pune, Pune, Maharashtra 411007, India \\ Email: ${ }^{1}$ sameer.m.padhye@gmail.com (corresponding author), ${ }^{2}$ hemantghate@gmail.com, ${ }^{3}$ kalpanapai@unipune.ernet.in
}

Abstract: Sampling in two freshwater bodies near Pune City, Maharashtra State located in the northern region of the Western Ghats revealed the presence of three species of clam shrimps. In this paper we provide new locality records of genera Caenestheriella sp. and Lynceus sp. from the northern region of the Western Ghats in Maharashtra State, India. We also provide some habitat description and information on ecological parameters of the water bodies.

Keywords: Branchiopods, clam shrimps, freshwater, India, new records, Pune

Large branchiopods are mostly found in temporary pools. The relatively rapid growth, maturation and the production of dormant stages make them highly adapted to the recurrent filling and drying of temporary pools, producing both aquatic and terrestrial phases (Brendonck et al. 1996).

The crustacean class Branchiopoda includes

Date of publication (online): 26 May 2011

Date of publication (print): 26 May 2011

ISSN 0974-7907 (online) | 0974-7893 (print)

Editor: Stephen C. Weeks

Manuscript details:

Ms \# 02486

Received 18 June 2010

Final received 15 December 2010

Finally accepted 04 January 2011

Citation: Padhye, S.M., H.V. Ghate \& K. Pai (2011). New locality records and additional information on habitats of three species of clam shrimps (Crustacea: Branchiopoda) from a region in northern part of Western Ghats (Sahyadris), India. Journal of Threatened Taxa 3(5): 1756-1763.

Copyright: (C) Sameer M. Padhye, Hemant V. Ghate \& Kalpana Pa 2011. Creative Commons Attribution 3.0 Unported License. JoTT allows unrestricted use of this article in any medium for non-profit purposes reproduction and distribution by providing adequate credit to the authors and the source of publication.

Acknowledgements: We would like to thank CSIR and UGC for providing the funds required for the study.

OPEN ACCESS | FREE DOWNLOAD clam shrimps (Spinicaudata, Laevicaudata, and Cyclestherida), tadpole shrimps (Notostraca), fairy shrimps (Anostraca) and cladocerans (Cladocera). It is a morphologically diverse group of ecologically important, largely freshwater organisms (Brendonck 2008).

Although clam shrimps (the suborders Laevicaudata, Spinicaudata, and Cyclestherida, formerly treated as the order Conchostraca; see Martin \& Davis 2001) are known from eastern Asia, records from Southeast Asia are rare (Martin et al. 2003).

Our knowledge of the distribution and ecology of large branchiopods of India is very poor. There have been very few studies of the biodiversity of clam shrimps from India. The first work on clam shrimps in India was done by Baird (1860) and was followed by Gurney (1906). It was then followed by taxonomic works by Nayar \& Nair (1968), Nair (1965), Royan \& Alfred (1971), Battish (1981), Balaraman \& Nayar (2004) and Prasad \& Simhachalam (2009). These works include very little information about clam shrimp habitats. So far, 35 species of clam shrimps have been reported from India (Prasad \& Simhachalam 2009), out of which only four species have been reported from Maharashtra. The Western Ghats is a biodiversity hotspot and new species are being discovered there regularly. There has been no detailed survey, as of yet, on the clam shrimp diversity from the Western Ghats.

Ghate et al. (2003) reported three species from Pune, though no reference material is present for confirmation nor is any detailed description presented in the paper.

There are, unfortunately, no reliable keys for species-level identification of Indian clam shrimps. 
Royan \& Alfred (1971), Battish (1981) and Balaraman \& Nayar (2004) have described a few Indian species; mainly new species of Lynceus. No type specimens were available for comparative studies, although some authors have deposited the reference material.

Collections from one pool and a small pond revealed three species of clam shrimps out of which two are new records to the northern Western Ghats: one species each from the genera Lynceus, and Caenestheriella and one species from the family Leptestheriidae were collected and studied.

\section{Materials and Methods}

Study sites: The pond in University of Pune was located near the main administrative building (18033'17.62'N \& 7349'26.80"E) (Image 1 C-D). It was a temporary pond, though there was water until the month of April. The Pune University pond has quite a diverse zooplankton fauna along with other groups of animals. Chara sp. of algae was abundant
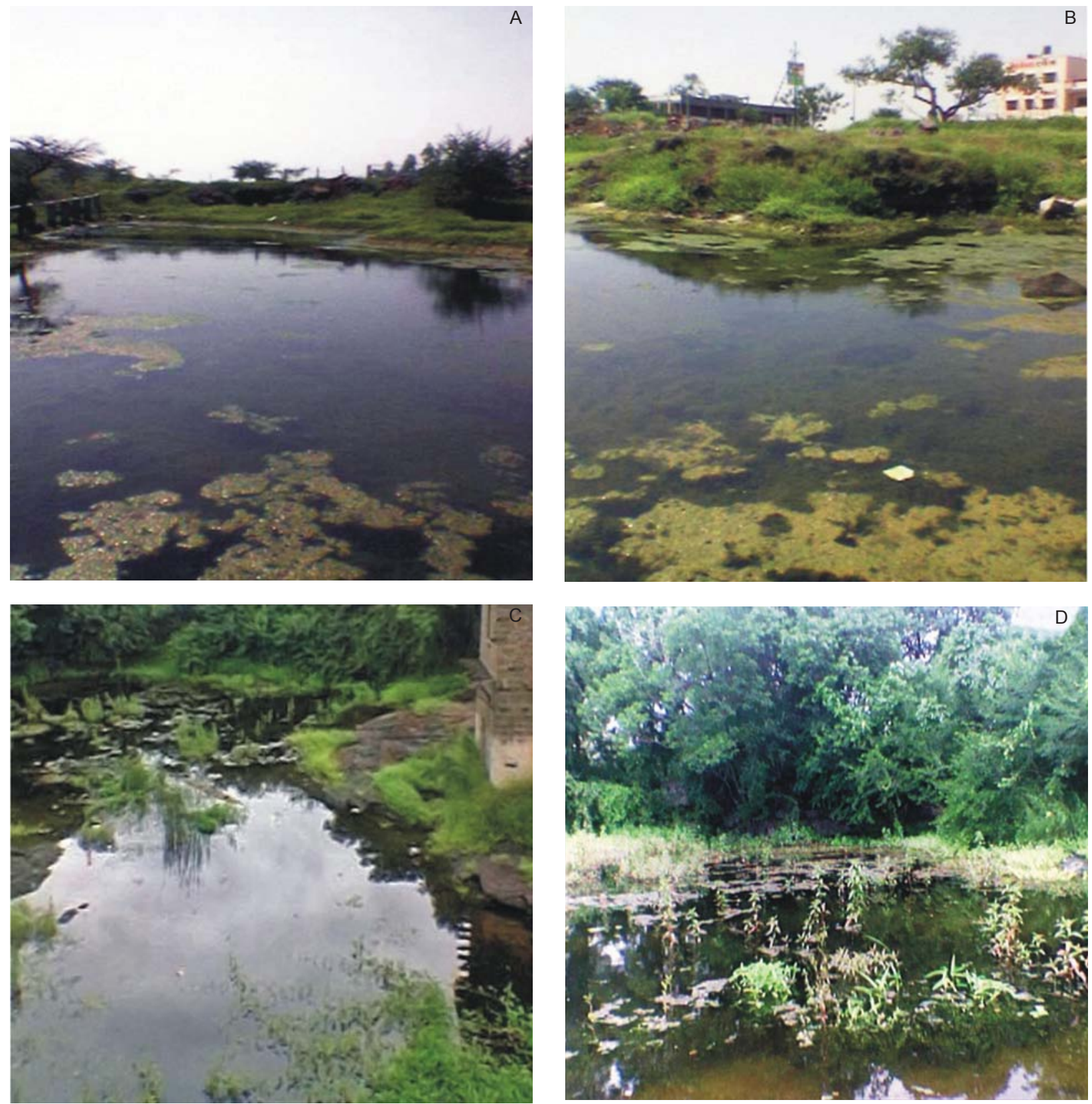

Image 1. A-B - Alandi Road pools; C-D - University of Pune pond 
at the site of collection. Depth of the pond varied from $6 \mathrm{~cm}$ to nearly $2 \mathrm{~m}$.

The second habitat was an ephemeral pool located on Alandi Road just on the outskirts of Pune City (1838'21.23”'N \& 73052'42.29”'E) (Image 1 A-B). It was a small pool and water was present from the start of monsoon till the month of November. Depth of the pool was around $12-15 \mathrm{~cm}$. Chara $\mathrm{sp}$. was also seen in this habitat.

Methods: Sampling took place with a net (mesh about $300 \mu \mathrm{m}$ ) swept at a depth of about $6 \mathrm{~cm}$ at both localities. Sampling was carried out in June and July 2009 in Pune University pond and in July and August 2009 in Alandi road pools. Quantitative sampling was started on 24 June 2009 and was continued once every week until the clam shrimps could not be seen (22 July 2009). It was done by filtering two litres of water from an approximately one square foot area from a single site and these quantitative observations were based entirely on the sampling from a single day. Only qualitative sampling was done for the other two species found in the pool on Alandi Road. All samples were preserved in $4 \%$ formalin. Physico-chemical properties (conductivity, salinity, and total dissolved solids) of both habitats were measured in the field with a portable EUTECH Multiparameter PCSTestr 35.

A stereo zoom microscope (Magnus MS 24) was used for dissections, as well as for general observations. A compound microscope (Magnus MLXi) was also used for observation of some morphological characters as well as photographic documentation.

Generic level identification for Lynceus sp. and Caenestheriella sp. and family level identification for the Leptestheriidae species was done by keys given by Martin \& Boyce (2004) and Thorp \& Covich (2001).

\section{Results}

One species from the family Leptestheriidae (Image $2 \mathrm{~A}-\mathrm{F}$ ) was found in a pond located on the campus of University of Pune. This was the only non cladoceran branchiopod seen in the habitat. The pond in the University had an abundance of Chara $\mathrm{sp}$., though the density decreased as the months progressed. The pond also had Hydrilla sp., though it was never seen at the site where the clam shrimp were found. Many cladoceran species, like Macrothrix spinosa, Ceriodaphnia cornuta, Simocephalus mixtus, were found in the pond. The $\mathrm{pH}$ of this pond gradually increased and stabilised at about 8 . Conductivity was higher for the University pond as compared to the Road pool. The average conductivity for Pune University pond was $1000 \mu \mathrm{S} \mathrm{cm}-1$. The temperature also fluctuated from 27 to $32{ }^{\circ} \mathrm{C}$ (Table1).

The specimen from the University pond belonged to family Leptestheriidae (Image $2 \mathrm{~A}-\mathrm{F}$ ) as the distal extremity of rostrum had a acute rostral spine in both sexes in adult (Martin \& Boyce 2004).

To check whether the species was Leptestheriella maduraensis (Nayar \& Nair 1968) and reported by Ghate et al. (2003) from Pune, we compared our specimen's characters with the characters given by Nayar \& Nair (1968) and found that the species at Pune University had some different characters. Because the literature and illustrations were not provided and there were no reference specimens, no definitive comparisons could be made. Characters showing similarity with $L$. maduraensis were the hairy margin of the shell (Image 2D) and distinct dorso-posterior shell morphology for males and females (Image $2 \mathrm{E}$ $-F)$. However, there were some characters that were different: the number of segments in the first and second antenna in males and females, telson with more than 28 spines on its dorsal edge and the furcal claw without any conspicuous spines.

Quantitative sampling of species from the family Leptestheriidae was started after its initial discovery in the pond. Weekly sampling revealed that the number of individuals were greatest on 24 June. The numbers quickly reduced and no clam shrimp could be seen after 22 July 2009 (Table 2). Three individuals were kept in the laboratory for observation and we noted that the shrimps in the lab survived for more than a month after last sighting in the pond. Some general observations seen were that the shrimps rested most of the time, either lying laterally or ventrally on the shell or by digging in the soil and burying themselves.

Table 1. Parameters of the two habitats studied.

\begin{tabular}{|l|c|c|}
\hline Parameters & $\begin{array}{c}\text { Alandi Road pool } \\
\text { (Mean } \pm \text { SE) }\end{array}$ & $\begin{array}{c}\text { Pune University } \\
\text { pond (Mean } \pm \text { SE) }\end{array}$ \\
\hline $\mathrm{pH}$ & $8.66 \pm 0.06$ & $7.97 \pm 0.029$ \\
\hline Temp & $30.2 \pm 0.35$ & $29.4 \pm 0.50$ \\
\hline Conductivity (uS/cm) & $450 \pm 6$ & $1005 \pm 35$ \\
\hline T.D.S (ppm) & $316 \pm 1.5$ & $712 \pm 24.6$ \\
\hline Salinity (p.p.t) & $0.22 \pm 3.5$ & $0.49 \pm 0.18$ \\
\hline
\end{tabular}



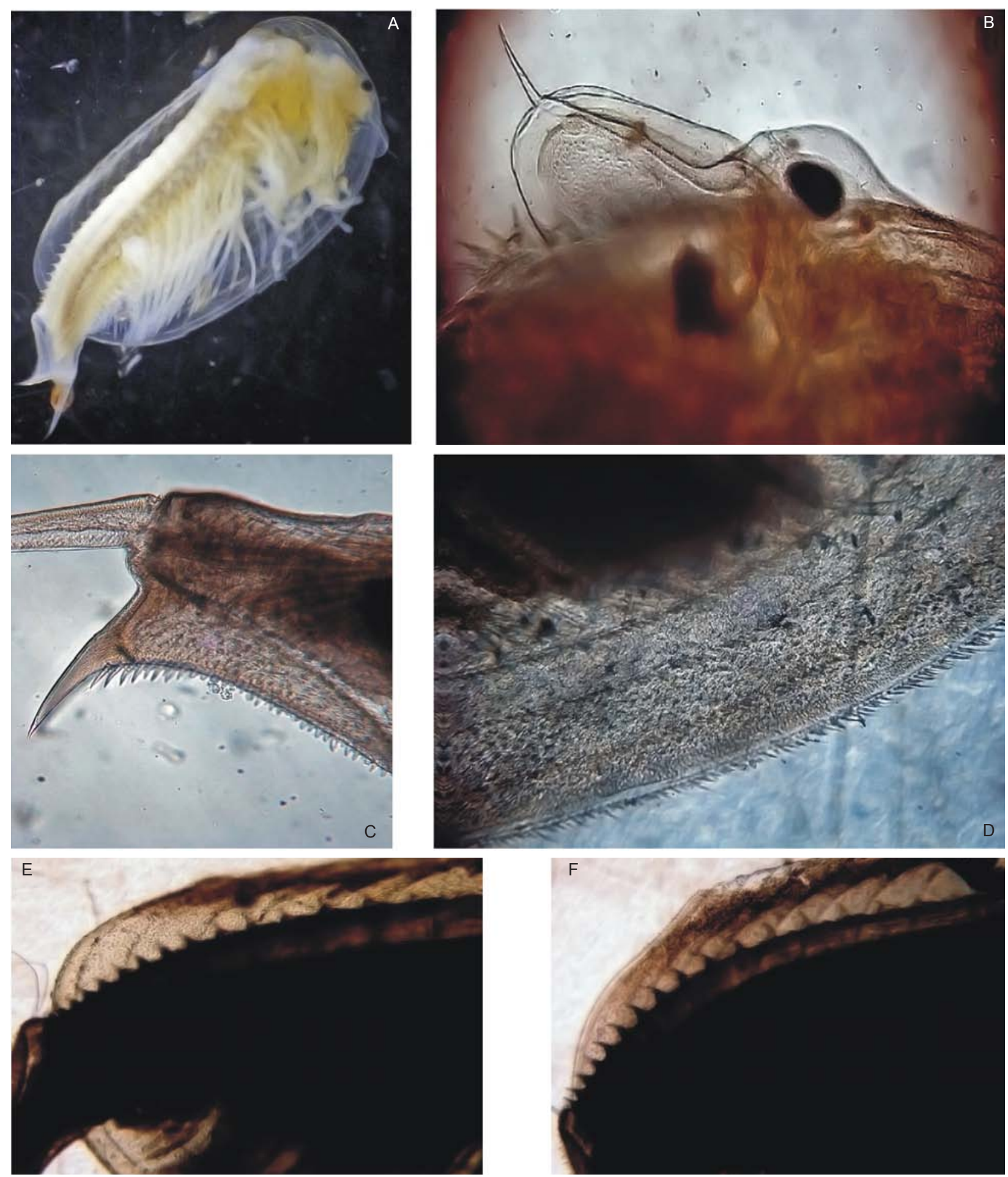

Image 2. A-F - Species from the family Leptestheriidae

A - Habitus; B - Head; C - Telson; D - Hairy margin of the shell; E - Dorso posterior margin of female shell; F - Dorso posterior margin of male shell)

Digging behaviour was seen more often than the other types. The posterior part of the body with the telson always remained out when the shrimps were buried in the soil. There was a sudden burst of activity seen in between the resting periods and this occurred randomly. These shrimps did not show any sensitivity towards light.

The clam shrimps from the road pools belonged 
Table 2. Quantitative sampling done from Pune University pond.

\begin{tabular}{|l|c|c|c|c|c|}
\hline Date & $\begin{array}{c}22 \text { June } \\
2009\end{array}$ & $\begin{array}{c}\text { 1 July } \\
2009\end{array}$ & $\begin{array}{c}8 \text { July } \\
2009\end{array}$ & $\begin{array}{c}15 \text { July } \\
2009\end{array}$ & $\begin{array}{c}22 \text { July } \\
2009\end{array}$ \\
\hline $\begin{array}{l}\text { Number of } \\
\text { individuals/L }\end{array}$ & 27 & 5 & 2 & 2 & 0 \\
\hline
\end{tabular}

to the genus Lynceus (Image $3 \mathrm{~A}-\mathrm{F}$ ) and the genus Caenestheriella (Image 4A-C) (Thorp \& Covich 2001; Balaraman \& Nayar 2004; Martin \& Boyce 2004).

The distinguishing characters for the genus Lynceus were: carapace valves without carapace lines (Image 3E), completely enclosing rostrum (Image 3B), a pair of sensory fields on either side of rostral carina, the first pair of thoracopods in males modified as claspers (Image 3F) and the caudal end lacking spine-like caudal furca (Image 3D) (Thorp \& Covich 2001; Balaraman \& Nayar 2004; Martin \& Boyce 2004).

Male and female rostra terminating in an acute point was the distinguishing characters for the genus Caenestheriella (Image 4B) (Thorp \& Covich 2001).

The pool by the Alandi road had a high density of Chara sp. There was a high density of Streptocephalus sp. (i.e., fairy shrimp, mostly $S$. dichotomus) in that pool. Triops granarius was also present, though in lower density. The physicochemical parameters were also recorded: average $\mathrm{pH}$ was 8.66 and temperature was $30.2^{\circ} \mathrm{C}$. Conductivity was about $450 \mu \mathrm{S} / \mathrm{cm}$ (Table 1). The pool dried out in the month of November.

Species level identification could not be made for Lynceus or Caenestheriella. We compared the Lynceus species found in the road pools with the species described by Royan \& Alfred (1971), Battish (1981) and Balaraman \& Nayar (2004), but the characters, (e.g., overall size and colour of the animal, possession of a characteristic row of serrations on the postero-ventral margin of the shell; see Image 3E), as described by Royan \& Alfred (1971), Battish (1981) and Balaraman \& Nayar (2004) were not seen in these specimens of Lynceus. Other characters, such as general head shape, $1^{\text {st }}$ and $2^{\text {nd }}$ antennae, telson and number of legs, were also compared. No reliable data or descriptions of Caenestheriella species in India could be found.

\section{Discussion}

The genus Leptestheriella is Gondwanan in distribution and hence is found in Africa, India, etc.
Lynceus, on the other hand, is a cosmopolitan genus (Brendonck et al. 2008).

In the past, coexistence of large branchiopod species was considered rare (Weise 1964). Since then, many studies have shown that, even within the different groups of large branchiopods, coexistence is not uncommon (Maeda-Martinez et al. 1997). MaedaMartinez et al.(1997) further summarised all potential factors facilitating large branchiopod coexistence and divided them into three categories: (i) habitat factors, (ii) species factors and (iii) historic factors. The Alandi road pools had an assemblage of all the three types of non-cladoceran branchiopods. Caenestheriella and Lynceus species of clam shrimps were seen coexisting in the road pools at the same time. Such coexistence of similar species may, at least partly, be accomplished through niche segregation, allowing species to partition resources in space or time (Begon et al. 1996). The university pond supported only the species from the family Leptestheriidae.

Biodiversity and ecological work on the Indian clam shrimps has been conducted in selected areas in India. Several studies have been focused on Kerala (Nair 1965; Nayar \& Nair 1968; Royan \& Alfred 1971; Balaraman \& Nayar 2004). Baird (1860) worked on the clam shrimps from Nagpur area. Gurney (1906) worked in Bengal. Battish (1981) has worked on Branchiopods in the Punjab region. Most of the type localities of Indian clam shrimps are from southern India, Rajasthan and northeastern India, except for Eulimnadia compressa and Cyclestheria hislopi described by Baird from Nagpur (Prasad \& Simhachalam 2009). There have been no detailed reports, as of yet, on the presence of clam shrimps from the Sahyadris (Western Ghats). Three species have been reported from Pune, Maharashtra (Ghate et al. 2003) though the report lacks any detailed description of the organisms or a habitat description. Another major problem is the absence of reference specimens for comparisons and the lack of reliable literature for study. The camera lucida drawings given by the Indian authors are also inadequate for identification to up to species. Literature on faunistic approaches for clam shrimps in India is completely absent.

Brendonck et al. (2008) have said that though clam shrimps have a worldwide distribution, they have not been studied extensively. He has stated that there are nearly 116 species of clam shrimps in the world. 

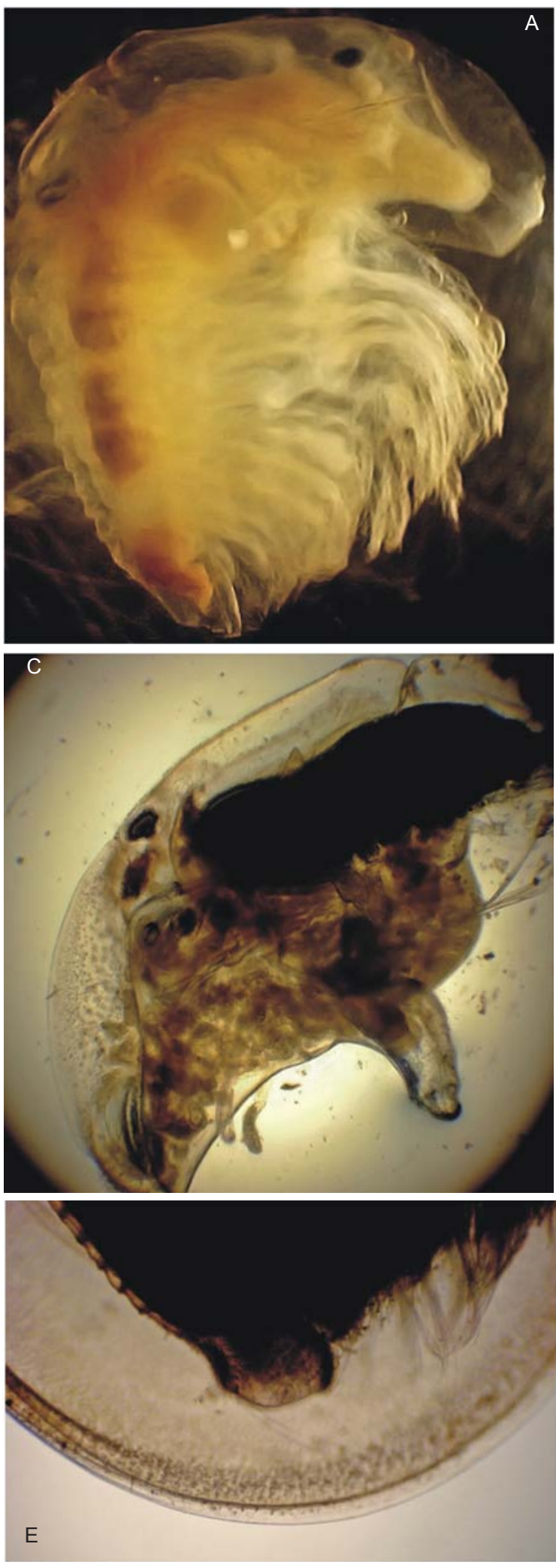

Image 3. A-F: Lynceus sp (A - Habitus; B - Rostrum enclosed in shell; C - Head; D - Telson; E - Carapace showing no lines of growth; $F$ - Clasper in male).
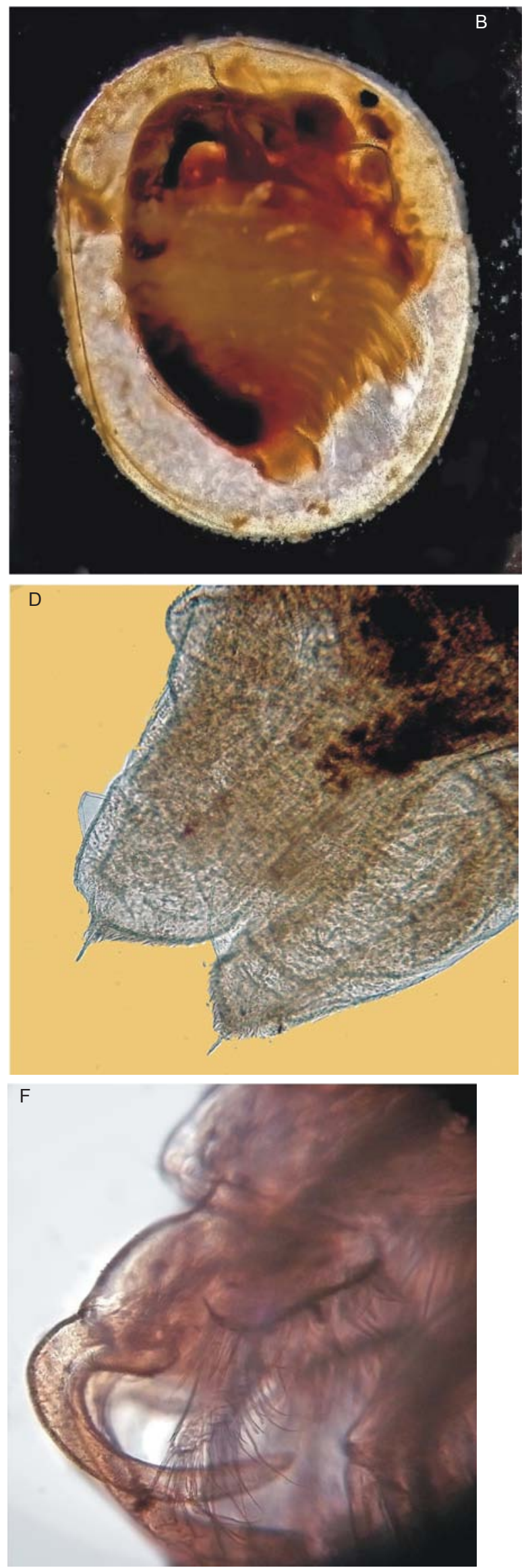

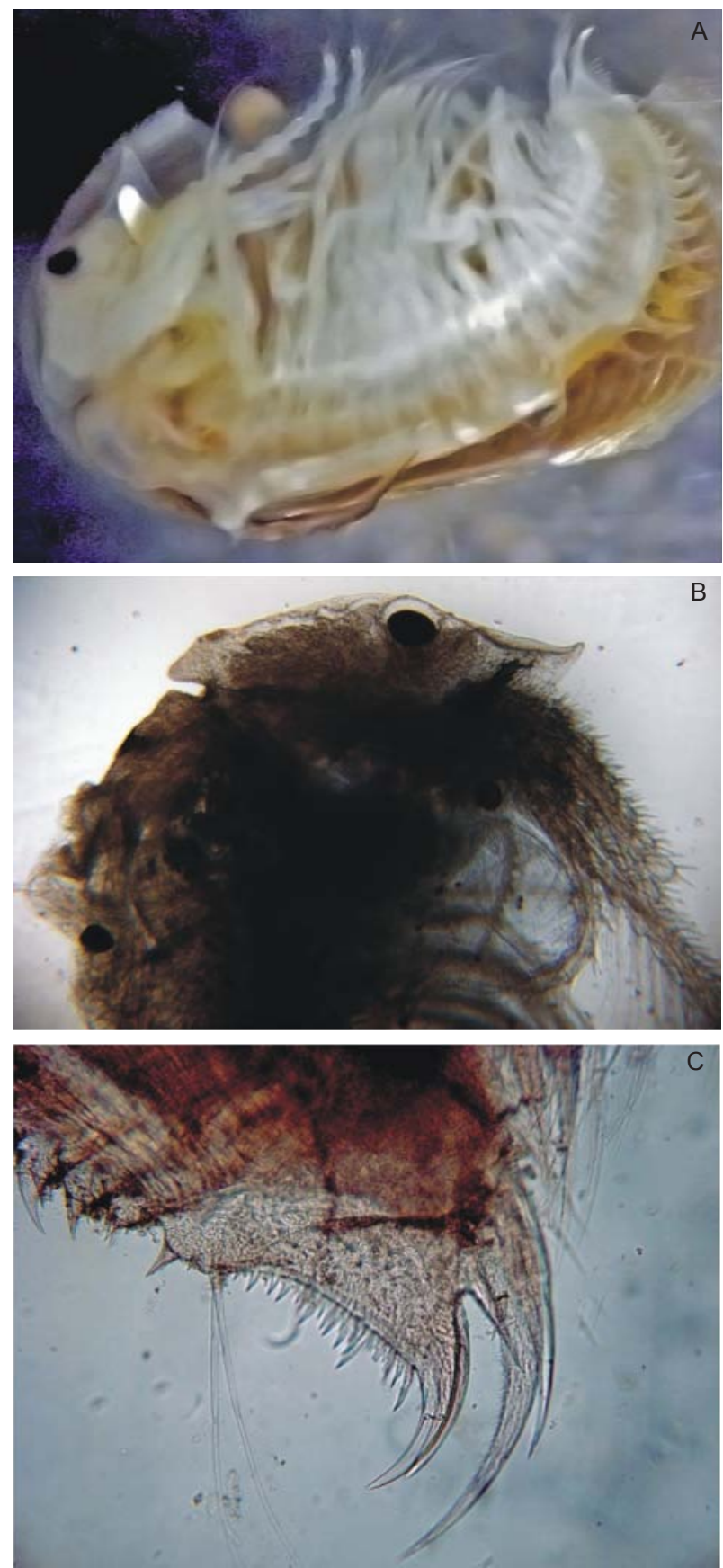

Image 4. A-C - Caenestheriella sp.

A - Habitus; B - Head; C - Telson

Prasad \& Simhachalam (2009) has reported 35 species of clam shrimps from India, in which he has stated that there is high endemism: 32 of these species are known only from India. Maharashtra State has not been faunastically surveyed for temporary water habitats, and it is our attempt to start this by first looking at habitats from Pune City.

There is a need to save temporary pool habitats from various human activities since they harbour many unique species of branchiopods (Witham et al. 1998). Human activities have deteriorated temporary pool habitats around the world. In developing countries no data as such are available but the conditions are likely to be the same due to rampant use of pesticides, land use and other activities (Brendonck \& Williams 2000; Brendonck et al. 2008). Hatching of eggs in branchiopods depends on various environmental conditions (Brendonck 1996; Brendonck \& De Meester 2003), such as temperature and salinity. These parameters are important as they play a vital role in the growth and reproduction of the branchiopods in that particular habitat (Brendonck 1996; Brendonck et al. 2008; Spencer \& Blaustein 2001). Due to lack of knowledge about such habitats and the endemism seen in clam shrimps in India, study and conservation of such habitats becomes very important. The pond on Alandi road is subject to organic pollution and dumping of garbage. The University pond, on the other hand, is less threatened as it falls in the University of Pune campus. There is a different problem for Pune University pond though, as guppy fish have been introduced many times into the pond for mosquito control, which poses a threat to the clam shrimps. Effects of this fish on reproduction of frogs in this pond have already been published (Ghate \& Padhye 1988). The current study is the initial phase in the total survey of habitats for temporary pools in the region and its biodiversity and ecology. Many habitats within the region are being destroyed for real estate development and this activity is spreading very fast. Hence further studies will definitely help our understanding of clam shrimp biodiversity and ecology from this part of Western Ghats, and hopefully will enable something concrete to be done about their conservation.

\section{REFERENCES}

Baird, W. (1860). Description of some new recent Entomostraca from Nagpur, collected by Rev. S. Hislop. Proceedings of the Zoological Society of London 28: 445-446.

Balaraman, U. \& C.K.G. Nayar (2004). A new species of the clam shrimp genus Lynceus (Branchiopoda Conchostraca, Laevicaudata) from Kerala, India. Crustaceana 77: 407416.

Battish, S. K. (1981). On some conchostracans from Punjab with the description of three new species and a new 
subspecies. Crustaceana 40: 178-196.

Begon, M., J.L. Harper \& C.R. Townsend (1996). Ecology: Individuals, Populations and Communities. Blackwell Science, Oxford Press, 1049pp.

Brendonck, L. \& W.D. Williams (2000). Biodiversity in wetlands of dry regions (drylands), pp. 181-194. In: Gopal, B., W.J. Junk \& J.A. Davis (eds). Biodiversity in Wetlands: Assessment, Function and Conservation. Backhuys Publishers, Leiden, The Netherlands.

Brendonck, L. (1996). Diapause, quiescence, hatching requirements: what we can learn from large freshwater branchiopods (Crustacea: Branchiopoda: Anostraca, Notostraca, Conchostraca). Hydrobiologia 320: 85-97.

Brendonck, L. \& L.De Meester (2003). Egg banks in freshwater zooplankton: evolutionary and ecological archives in the sediment. Hydrobiologia 491: 65-84.

Brendonck, L., C. Rogers, J. Olesen, S. Weeks \& W. Hoeh (2008). Global diversity of large branchiopods (Crustacea: Branchiopoda) in freshwater. Hydrobiologia 595: $167-$ 176.

Ghate, H.V., N. Rane \& S.G. Patil (2003). New record of Conchostraca (Crusteacea) from Pune, Maharashtra Zoos ‘ Print Journal 18(3): 1046.

Ghate, H.V. \& A.D. Padhye (1988). Predation of Microhyla tadpoles by Gambusia. Journal of the Bombay Natural History Society 85: 200-201.

Gurney, R. (1906). On some freshwater Entomostraca in the collection of the Indian Museum. Journal of Asiatic Society of Bengal 2: 273-281.

Maeda-Martinez, M.A., D. Belk, O.H. Barboza \& H. Dumont (1997). Large branchiopod assemblages common to Mexico and the United States. Hydrobiologia 359: 4562.

Martin, J.W. \& G.E. Davis (2001). An updated classification of the recent Crustacea. Natural History Museum of Los Angeles County Science Series 39: 1-164.
Martin, J.W. \& S.L. Boyce (2004). Crustacea: non-cladoceran Branchiopoda, pp. 284-297. In: Yule C.M. \& H.S. Yong (eds.), Academy of Sciences, Malaysia.

Martin, J.W., S.L. Boyse \& M.J. Grygier (2003). New records of Cyclestheria hislopi (Baird, 1859) (Crustacea: Branchiopoda: Diplostraca: Cyclestherida) in South East Asia. The Raffles Bulletin of Zoology 51(2): 215-218

Nayar, C.K.G. (1965). Three new species of Conchostraca (Crustacea: Branchiopoda) from Rajasthan. Bulletin of Systematic and Zoology 7: 19-24.

Nayar, C.K.G \& K.K. Nair (1968). On a collection of Conchostraca (Crustacea: Branchiopoda) from South India, with a description of two new species. Hydrobiologia 32: 219-224.

Prasad, M.K.D. \& G. Simhachalam (2009). Distribution of Indian clam shrimps (Branchiopoda: Crustacea). Current Science 96(1): 71-74.

Royan, J. \& J.R.B. Alfred (1971). Lynceus serratus sp. nov. (Conchostraca, Lynceidae) from southern India. Crustaceana 21: 37-40

Spencer, M. \& L. Blaustein (2001). Hatching responses of temporary pool invertebrates to signals of environmental quality. Israel Journal of Zoology 47: 397-417.

Thorp, J.P. \& P.M. Covich (2001). Ecology and Classification of North American Freshwater Invertebrates. Academic Press, 1073pp.

Weise J.G. (1964). An aggregation of phyllopods. Transactions of the Kansas Academy of Sciences 67: 206-207.

Witham, C.W., E.T. Bauder, D. Belk, W.R. Ferren Jr. \& R. Ornduff (1998). Ecology, Conservation, and Management of Vernal Pool Ecosystems - Proceedings from a 1996 Conference. California Native Plant Society, Sacramento, CA, 147-150pp. 